\title{
TEACHING SPEAKING USING COLLABORATIVE APPROACH AT SENIOR HIGH SCHOOL IN WEST BANDUNG
}

\author{
Acep Haryudin ${ }^{1}$, Yana $^{2}$, Efransyah $^{3}$ \\ ${ }^{1}$ IKIP Siliwangi \\ ${ }^{2}$ IKIP Siliwangi \\ ${ }^{3}$ IKIP Siliwangi \\ ${ }^{1}$ haryacep@ gmail.com, ${ }^{2}$ yanaenglish.edu@gmail.com, ${ }^{3}$ efransbae@ gmail.com
}

\begin{abstract}
The objectives of this research are to figure out the significant improvement and achievement of Collaborative Approach in teaching speaking. The method of this research is quantitative method. The population was the tenth grade students of SMAN 2 Padalarang and the sample was consisted of 30 students of tenth grade students. The instruments were pretest-posttest. The data was analyzed using descriptive statistic. The $t$ test data score was 0.000 . The score was less than 0.05 . So the null-hypothesis was rejected. Therefore, it can be concluded that there was a significant improvement and achievement of Collaborative Approachin teaching speaking. In the other words that collaborative approach can develop the students' ability of critical thinking, creativity, sincerity, formulating question, self confidence and communication skill. Problem solving and self reflection. The students' difficulties in speaking is difficult in pronunciation, afraid of making mistakes, mother tongue used, lack of vocabulary and lack of curiosity.
\end{abstract}

Keywords: Speaking, Collaborative Approach

\section{INTRODUCTION}

Speaking is the tool of communication. It is used to communicate with other people in the environment. It is the most important skill from other language skills. Thornbury \& Slade (2007: 1) said through speaking we can establish, maintain and modify our identities. The role that conversation plays in our formation as our social beings starts at an early age. People involved in conversation since they were infants even when they do not learn the language yet. They begin to recognize words by word until they are able to produce it and people use speaking to communicate. Example when children communicate with their parent or their playmates.

Speaking also an interactive process of constructing meaning, involving producing, receiving and processing information (D. Brown, 2001: 267). The researcher's response toward this definition that before someone try to speak, they need to think and build the meaning in their mind first, next they need to process the information then finally utter the sentence perfectly with the well structure and can be understood, this can call speaking cycle (receive inputconstructing meaning- process the information- produce it). In addition, according to Brown (2001: 140) speaking is a productive skill that can be directly and empirically observed, those observations are invariably colored by the accuracy and effectiveness of a test-taker's listening skill, which necessarily compromises reliability and validity of an oral production test. This means that speaking and listening skills are closely intertwined. 
People can get information from what they have listened then share that information again based on their comprehension or they can share based on their own experience. However a student may be good at listening and understanding, it need not follow that he will speak well. A discriminating ear does not always produce a fluent tongue. There has to be training in the productive skill of speech as well (Broughton, et al, 2003). But, in many cases, listening should lead naturally on to speaking. This is particularly so at the phonological level where it essential to develop an ability to recognize a sound before success in producing it is possible.

However, the critical problem that is faced by most of students especially in SMA N 2 Padalarang is how to be able to speak English well, frequently and accurately. In the real situation, there are so many obstacles that prevent students to speak and will make the students become passive learners like afraid of making mistakes in grammar and word order, very limited of vocabulary, no ideas to say, and they were too comfort to speak Sundanese as their mother tongue. They felt that English is not important for them because they are Indonesian and they do not speak in English. The students didn't care toward the language learning, they did not aware how important English toward their bright future. so, this is a challenge for researchers to find out the extent of English language difficulties especially speaking skills for students, and how to improve their speaking skills.

\section{Elements of Speaking}

The ability to speak fluently presupposes not only knowledge of language features, but also the ability to process information and language "on the spot". According to Harmer (2007: 269) there are two elements of speaking:

\section{a. Language features}

Among the elements necessary for the spoken production (as opposed to the production of practice examples in language drills), are the following:

1. Connected speech: effective speakers of English need to be able not only to produce the individual phonemes of English but also to use fluent connected 'speech'. So, the teacher should involve students in activities designed to improve their connected speech.

2. Expressive Devices: native speakers of English change the pitch and stress of particular parts of utterances, vary volume and speed and show by other physical and non- verbal. The use of this devices contributes to the ability to convey meanings. They allow the extra expression of emotion and intensity. Students should be able to deploy at least some of such suprasegmental features and devices in the same way if they are to be fully effective communicators.

3. Lexis and grammar: spontaneous speech is marked by the use of number common lexical phrases, especially in the performance of certain language functions. Teacher should therefore supply a variety of phrases for different functions where students involved in specific speaking contexts.

4. Negotiation language: effective speaking benefits from the negotiator language we use to seek clarification and to show the structure of what we are saying. For students, this is especially crucial. They use negotiation language to show the structure of their thoughts or reformulate of what they are saying in order to be clearer, especially when they can see that they are not being understood.

\section{b. Mental or social processing}

If part of speaker's productive ability involves the knowledge of language skills, success is also dependent upon the rapid processing skills that talking necessities.

1. Language Processing: Effective speakers need to able to process language in their own heads and put it into coherent order so that it comes out in forms that are not only comprehensible, but also convey the meanings that are intended. One of the main 
reasons for including speaking activities in language lesson is to help students develop habits of rapid language processing in English.

2. Interacting with others: most speaking involves interaction with one or more participants. This means that effective speaking also involve a good deal of listening and understanding of how the other participants are feeling, and a knowledge of how linguistically to take turns or allow others to do so.

3. (On-the-spot): quite apart from response to others' feeling, it also need to be able to process the information they tell us the moment we get it. The longer it takes the 'penny to drop' the less effective we are as instant response communicators.

\section{Aspects of Speaking}

Assessment is needed to know the students' basic knowledge and to know their improvement toward the teaching language. According to Hughes (2003: 111) there are five aspects in measuring the students' speaking skill, they are :

\section{a. Pronunciation}

Pronunciation is the way how to produce or to pronounce words. It is as the production and reception of sounds of speec Errors in pronounce words will affect the meaning of the words itself. The meaning will be different. People usually assess someone's speaking skill through pronunciation, that is why students with good pronunciation generally categorized as the students who has good English too because it sounds like native speaker and their speaking are easier to understand.

\section{b. Grammar}

Grammar can be defined as the rules of that language. Grammar is a set of rules that explores the forms and structures of sentences that can used in a language (Gleason and Ratner, 2009) in (Uibu \& Liiver, 2015). Grammar has the history to be the most boring and difficult aspect to be learnt. Therefore, student who is good in grammar will be able to speak accurately.

\section{c. Vocabulary}

Vocabulary can be defined, roughly as the words we teach in the foreign language. However, a new item of vocabulary may be more than a single word, it can be phrase or idioms (Ur, 1996). Very limited vocabulary will make the speech is virtually unintelligible.

\section{d. Fluency}

According to Yang (2014) fluency is the ability to talk at length with few pauses and it is the ability to be able to produce sentences coherently, reasoned and semantically. So, fluency can be defined as the speed of speaking and the ability to produce language when sharing ideas, then how the sequence of words can be arranged well. It considered being the ability to keep going when speaking spontaneously and fluency is the ability to read, speak, or write easily, smoothly, and expressively. In other word, the speaker can read, understand and respond the language clearly and concisely while relating meaning and context (Purnamawati 2015).

\section{e. Comprehension}

When someone asking to talk about something. If they have good comprehension about the topic of being asked, their desire to speak will raise and can share their mind fluently. This is means comprehension. It is someone's ability to understand something.

\section{Collaborative Approach}

\section{a. Definition of Collaborative approach}

Collaborative approach is one of teaching method which required students to work in small group. Studying in a group will make students become more interactive 
students and working in group will enhance the student's comprehension through discussion. There are some definitions of Collaborative approach according to experts.

Moreillon (2007:6) stated that Through collaborative teaching educators develop a common language, a common set of practices, and channels for communication that can increase student learning and help the entire school community better serve the academic and social needs of students and families. Collaborative approach also holds enormous promise for improving student learning and revitalizing college teaching. It is a flexible and adaptable method, appropriate to any discipline.

Roberts (2004) stated that collaborative approach is an adjective that implies working in a group of two or more to achieve a common goal, while respecting each individual's contribution to the whole. It is a learning method that uses social interaction as a means of knowledge building. In Collaborative approach Educator as Collaborative 'Facilitator' and Collaborative approach occurs among students within groups both in and outside class. Groups work as a team but submit their work as individuals.

The term of Collaborative approach often used interchangeably with cooperative, but they have different meaning. More recently he has suggested that "in collaboration, partners do the work 'together," whereas "in cooperation, partners split the work, solve sub-tasks individually and then assemble the partial results into the final output". So based on the definition above, the researcher concluded that collaborative approach is teaching method that is used in teaching learning where the students work in group to achieve their common goal. It is the situation where the students study together, here the students exploit the ability of each member of the group. they share about their knowledge, their experience and also their skill. In collaborative approach the students do the task where they are correlated one each other and responsible one to another. This approach involve the students' activeness and to minimize the differences between of each individual.

Sometimes no students volunteer to answer. Most of students do not want to participate or even to share their ideas in the whole activities because they do not believe with their own knowledge that they are sometimes right. Through Collaborative approach, students can share their ideas with their group. Besides, students' differences perspective and comprehension expected can increase and add the knowledge of each member of the group especially in improving their speaking skill. In collaborative approach, the students must responsible to complete the task. They work together and their participations also needed to solve the problem on their assignment and present it together, each member must be able to explain what they have done.

b. Teaching Speaking Using Collaborative approach

Based on the explanation above, teaching speaking using collaborative approach means that students can practice their speaking in a group by sharing their comprehension to their friends first then present their assignment again to the whole class. Tint \& Nyunt (2015) said that Collaborative approach makes students to learn more intensely their education and to think about their interest fields and to apply variety of settings. There are many techniques available for collaboration. Some of the collaborative techniques are: a) Fishbowl, b) Jigsaw, c) Paired Annotations, d) Think-Pair-Share (TPS). From all the techniques, in this research the researcher used Think-Pair-Share (TPS) to enhance the students' speaking skill in the experimental 
class. The further discussion of this technique will be discussed in the next part of this chapter.

\section{c. The advantages of Collaborative approach}

According to Weller (2002) explains that collaborative approach in small group has some advantages:

1. The first advantage is reflection, because all of the students have to explain Reviews their ideas or share Reviews their work. This forces them to look at it reflectively and improve Reviews their own knowledge. He also explains that by sharing with Reviews their friends, they definitely more brave and do not scare anymore. Students may explain the topic better that the teacher to the students.

2. Become active learning. As with the other theories, grouping students working requires them to be more active to do something. As what had been explained before, working together becomes a chance for students to be braver, critics and showing Reviews their abilities. The development of communication skills. Students work in group can be difficult, skills to develop, but the students will learn it by Reviews their friends. In the discussion session, the students may learn the concept well and observe the thought process of others. They also have enough time to practice their speaking in the classroom and they have the same time to speak.

3. Deeper understanding. Working collaboratively can improve each student's understanding of the concept, even that of the strongest student, compared with that gained working individually. There is a Gestalt effect, the whole being greater than the sum of the parts. In addition, the students can explain the material based on their own words and it can enrich their vocabulary.

4. Broader scope. Each student can bring something different to the task, whether it is a skill, or knowledge he or she has acquired specifically for the activity. The group can thus cover a broader range of topics, read more articles or achieve tasks that could not have been done individually in the given time.

5. Exposure to different ideas. As with resource based learning, collaborative approach can mean students are exposed to different viewpoints, as their fellow students have different concepts and experiences.

\section{METHOD}

Method is the steps that the researcher do to collect the data or information. In other words, method is a style of conducting research work which is determined by the nature of the problem (Singh, 2007). In addition, Tavakoli (2012) stated that Research methodology defines the kinds of problems that are worth investigating and frames them, determines what research approaches and research methods to use, and also how to understand what constitutes a legitimate and warranted explanation. Generally research method can be classified into three broad categories, they are qualitative, quantitative and mixed method. It is supported by Tavakoli (2012), research design can be classified into three broad research categories; quantitative research, qualitative research and mixed methods research designs. The method used in this research is quantitative method with quasi experimental design (Creswell, 2014). According to Tavakoli (2012; 277), instrument is any device that can be presented in written, audio or visual format, which is used to collect the data. The instrumentts of this research is oral test (pretest and posttest) Test is made to get the students' score of pretest and postest. Test was admistered by each students. Pretest is used to measure the students' basic ability of speaking skill and posttest is used to know the effect of the treatment toward the students. 


\section{RESULTS AND DISCUSSION}

\section{Results}

\section{Descriptive Statistic}

Descriptive statistic is administered to know the students basic skill of speaking in both control and experimental classes before treatment.

Table 1

Descriptive Statistic of Control and Experimental Class

\begin{tabular}{cccccccc}
\hline Variable & \multicolumn{3}{c}{ Control Class } & \multicolumn{4}{c}{ Experimental Class } \\
\hline $\begin{array}{c}\text { Speaking } \\
\text { Skill }\end{array}$ & & Pretest & Posttest & N- Gain & Pretest & Posttest & N- Gain \\
\cline { 2 - 8 } & $\mathrm{N}$ & 30 & 30 & & 30 & 30 & \\
\cline { 2 - 8 } & Mean & 45.5 & 70.4 & 0.46 & 44.9 & 84.3 & 0.72 \\
\cline { 2 - 8 } & Maximum & 76 & 88 & 0.73 & 72 & 92 & 0.87 \\
\cline { 2 - 8 } & Minimum & 20 & 56 & 0.4 & 28 & 64 & 0.6 \\
\cline { 2 - 8 } & Std. Deviation & 14.229 & 10.136 & 0.22996 & 13.191 & 7.373 & 0.16806
\end{tabular}

To determine the students' basic skill of speaking before treatment and how well the students' improvement after treatment. Acccording to Sadikin, Suprijadi, \& Kaswan (2019) there are three scale of gain score such as:

Table 2

Scale of Gain Score

\begin{tabular}{crl}
\hline No & Skor & \multicolumn{1}{c}{ Kategory } \\
\hline 1 & $24-47$ & Low range \\
\hline 2 & $48-71$ & Medium range \\
\hline 3 & $72-95$ & High range
\end{tabular}

Based on the table 1 the mean pretest of Control class is 45.46 . That score is in the range 2447 which means that the students' basic skill of speaking before giving the treatment is low. Besides, table 2 the mean pretest of Experimental class is 44.93. That score is in the range 2447. It means that the students' basic skill of speaking before treatment is low.

Based on the table 1, the mean posttest score of control class is 70.4. Based on the range, this score consisted of medium range because that mean score is in the range 48-71. So it can be concluded that the ability of students' speaking after giving the treatment is medium. Besides, the mean posttest score of experimental class is 84.3. Based on the range score criteria, this score classified as the high range which means that the ability of students' speaking is high.

\section{Data Analysis of Pretest}

Pretest is administered to know the students' basic knowledge and ability of speaking. Control and experimental class have the same task to assess their basic skill. After conducting the test, the researcher got the score of each students in control and experimental class.

\section{Normality}

Normality test is administered to measure each data obtained by both classess come from population with normal distribution or not. Normality test calculated from the total data of pretest score in both experimental and control class. To measure the normality of pretest data, it can be seen by comparing the coefficient sig with the probability standard 0.05 . If the sig more than 0.05 , it can be concluded that the data is normal.

Besides, if the sig less than 0.05 , it can be concluded that the data is not normal. From the data calculation with software SPSS 17 Version for windows, the data is obtained as follow: 
Table 3

Normality Test of Pretest

\begin{tabular}{|c|c|c|c|c|c|c|c|}
\hline \multicolumn{8}{|c|}{ Tests of Normality } \\
\hline \multirow{2}{*}{\multicolumn{2}{|c|}{ Kelas }} & \multicolumn{3}{|c|}{ Kolmogorov-Smirnov ${ }^{\mathrm{a}}$} & \multicolumn{3}{|c|}{ Shapiro-Wilk } \\
\hline & & Statistic & Df & Sig. & Statistic & Df & Sig. \\
\hline \multirow[t]{2}{*}{ Pretest } & Control & .133 & 30 & 187 & .976 & 30 & .711 \\
\hline & Experimental & .123 & 30 & $.200^{*}$ & .933 & 30 & .061 \\
\hline
\end{tabular}

Based on the table 4.3 above, the researcher used the data in Kolmogorov because the participant of this research is 30 students. In Kolmogorov show that the significance of gain score of control class is 0.187 . It means that the sig score more than sig 0.05 , so it can be concluded that the data

pretest of control class is normal. Besides, the significance of gain score of experimental class is 0.200 , the score also more than sig 0.05 , so it can be concluded that the pretest data of experimental class is normal distribution. From the explanation, the researcher concluded that the pretest data in both control and experimental class is normal distribution.

\section{Homogeneity}

After test of normality, if the data is normal distribution, the next test is homogeneity test. This test is administered to know whether the variance of two or more group score is homogen or not different significantly. The result of homogeneity test of pretest score is as follow:

Table 4

Homogeneity Test of Pretest

\begin{tabular}{lllll}
\hline \multicolumn{5}{c}{ Test of Homogeneity of Variance } \\
\\
Pretest Based on Mean & Levene Statistic & df1 & df2 & Sig. \\
Based on Median & .021 & 1 & 58 & .887 \\
Based on Median and with adjusted df .017 & 1 & 58 & .897 \\
Based on trimmed mean & .017 & 1 & 56.393 & .897 \\
& .022 & 1 & 58 & .883
\end{tabular}

There are some result in the table 4.4, but the result of homogeneity test is in Based on Mean. Table 4.4 shows that pretest score in both group classes (Control and Experiment) is homogenous because the sig is 0.887 , it is more than sig 0.05 . Because the data is homogemous, so the next step is t test.

\section{T Test}

Both of Control and experimental class is normal distribution and homogen. That is as the prerequisite before $t$ test. To determine whether the mean score of the two class is significant different or not, the researcher administer t test using SPSS 17 version for windows with Independent Sample T- Test. The standard significance is 0.05 . Those hypothesis is formulated in the form of statistic hypothesis (sig 2- tailed) as follow:

$\mathrm{H}_{0}$ : There is no difference between students' pretest in Control and Experimental class. $\mathrm{H}_{1}$ : There is a difference between students' pretest in Control and Experimental class. To get the result, the criteria should be: If $\mathrm{sig} \geq 0.05$ means that $\mathrm{H}_{0}$ is accepted. If sig $<0.05$ means that $\mathrm{H}_{0}$ is rejected.

After processing the data, the output for $t$ test can be seen in the table 4.6 below: 
Table 5

Independent $t$ Test of Pretest

Independent Samples Test

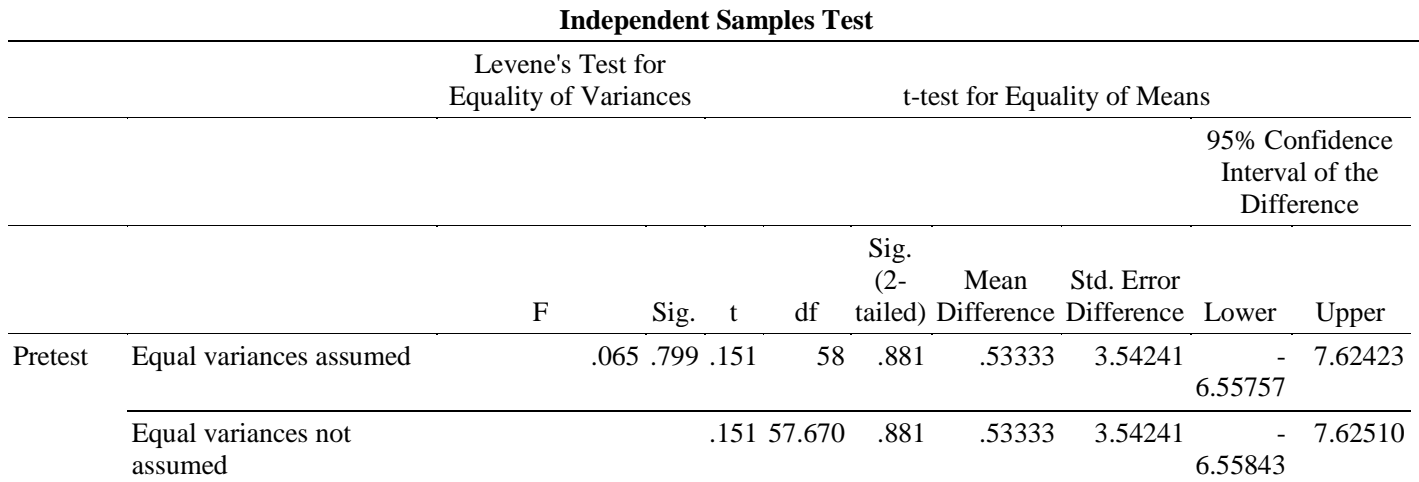

Table 5 shows that the significance score (sig 2- tailed) with t test is 0.881 . The probability score is more than 0.05 means that $\mathrm{H}_{0}$ is accepted, so it can be concluded that there is no differences between students' pretest in Control and Experimental class.

\section{Discussion}

\section{Data Analysis of Posttest}

Posttest is administered to know the students' improvement and achievement after giving the treatment. The question of posttest is same with the question in pretest, but in posttest, the researcher make some modification. After conducting the posttest, the researcher got the students' score of experimental and control class.

\section{Normality}

Normality test in posttest is administered to measure each data obtained by both classess come from population with normal distribution or not. Normality test calculated from the total data of postest score in both experimental and control class. To measure the normality of posttest data, it can be seen by comparing the coefficient sig with the probability standard 0.05 . If the sig more than 0.05 , it can be concluded that the data is normal. Besides, if the sig less than 0.05, it can be concluded that the data is not normal. From the data calculation with software SPSS 17 Version for windows, the normality of posttest data is obtained as follow:

\section{Table 6}

Test Normality of Posttest

\begin{tabular}{|c|c|c|c|c|c|c|c|}
\hline \multicolumn{8}{|c|}{ Tests of Normality } \\
\hline & & Kolmogor & Smirno & & & ro-Wilk & \\
\hline \multicolumn{2}{|c|}{ Class } & Statistic & Df & Sig. & Statistic & $\mathrm{df}$ & Sig. \\
\hline \multirow[t]{2}{*}{ Posttest } & Control & .144 & 30 & .113 & .926 & 30 & . 040 \\
\hline & Experimental & .125 & 30 & $.200^{*}$ & .957 & 30 & .262 \\
\hline
\end{tabular}

Based on table 7, the result of normality test is in Kolmogorov because the participant of this research is 30 students. The table shows that the sig score of the posttest of control class is 0.113 and the sig score of the posttest of experimental class is 0.200 . It means that the sig score of the two classes is more than 0.05 , so it can be concluded that the posttest score of control and experimental class is normal distribution.

\section{Homogeneity}

After calculating normality test in the two posttest data which the result is normal distribution, so the next step is homogeneity test. This test is administered to know whether the population of control and experimental class have the equal variance or not. The test is calculated using 
SPSS 17 Version for windows with standard significance is 0.05 . The result of homogeneity test of posttest score as follow:

Table 7

Homogeneity Test of Posttest

\begin{tabular}{|c|c|c|c|c|}
\hline \multicolumn{5}{|c|}{ Test of Homogeneity of Variance } \\
\hline & $\begin{array}{l}\text { Levene } \\
\text { Statistic }\end{array}$ & df1 & df 2 & Sig. \\
\hline Posttest Based on Mean & 3.831 & 1 & 58 & .055 \\
\hline Based on Median & 3.645 & 1 & 58 & .061 \\
\hline $\begin{array}{l}\text { Based on Median and with } \\
\text { adjusted df }\end{array}$ & 3.645 & 1 & 53.803 & .062 \\
\hline Based on trimmed mean & 3.778 & 1 & 58 & .057 \\
\hline
\end{tabular}

If we see the result of homogeneity test on the table 8 above, the sig score is 0.05 . It means that the sig score is more that 0.05 , so it can be concluded that the data of control and experimental posttest score comes from population with equal variance or those class are homogen.

\section{T Test}

If the data in Control and experimental class is normal distribution and homogen, the next test is $t$ test. The researcher administer $t$ test using SPSS 17 version for windows with Independent Sample T- Test. The standard significance is 0.05 . Those hypothesis is formulated in the form of statistic hypothesis (sig 2- tailed) as follow:

$\mathrm{H}_{0}$ : There is no difference between students' posttest in Control and Experimental class.

$\mathrm{H}_{1}$ : There is a difference between students' posttest in Control and Experimental class.

To get the result, the criteria is:

If $\operatorname{sig} \geq 0.05$ means that $\mathrm{H}_{0}$ is accepted.

If $\operatorname{sig}<0.05$ means that $\mathrm{H}_{0}$ is rejected.

After processing the data, the output for $t$ test can be seen in the table below:

Table 8

T Test of Posttest

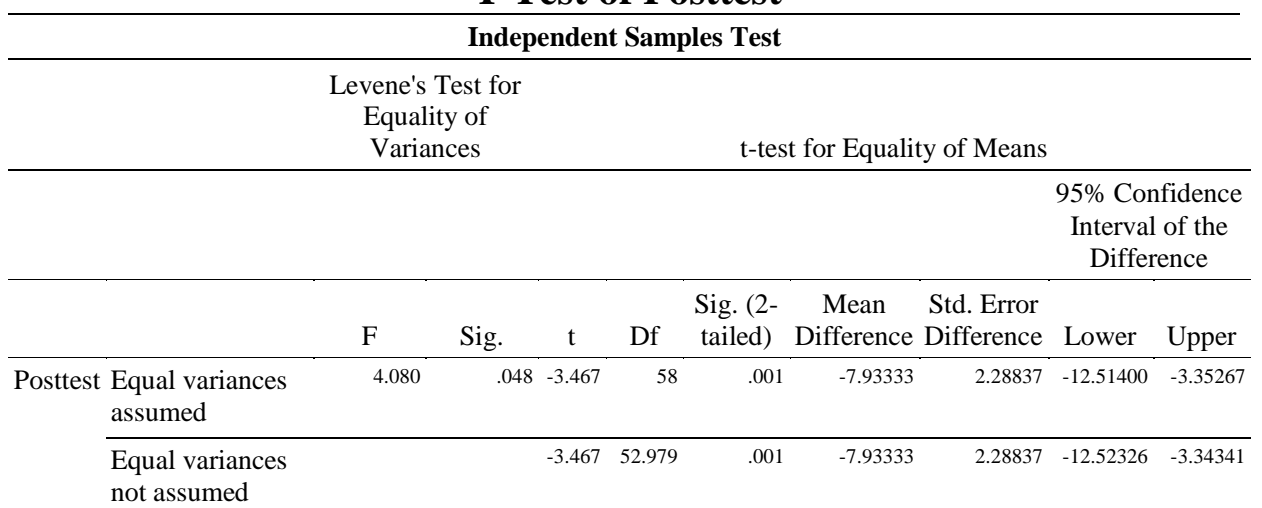

Based on the table, the result shows that the sig is 0.01 . It is less than 0.05 , means that $\mathrm{H}_{0}$ is rejected. So the conclusion is that there is a difference between students' posttest in Control and Experimental class. 


\section{CONCLUSION}

Teaching speaking using Collaborative approach is able to give the significant improvement and achievement toward the students' speaking skill. The Independent T- test of posttest show that the significant value was 0.01 . This score was lower than $0.05(0.01<0.05)$. It means that $\mathrm{H}_{0}$ is rejected. In the other words, it can be concluded that there is a difference between students' posttest in Control and Experimental class. The significant difference can be seen from the previous data analysis of $\mathrm{N}$-gain. Independent $\mathrm{T}$ - test of $\mathrm{N}$ gain score shows that the significant was 0.00 . That the score is lower than $0.05(0.00<0.05)$. It means that $\mathrm{H}_{0}$ is rejected. In the other words, it can be stated that there is a significant improvement and achievement teaching speaking using collaborative approach. The students improvement and achievement of collaborative class is categorized as high because the score is in the scale $0.71-1.00$.

The students' difficulties when they were taught by using collaborative approach with TPS technique are the same groupmates in every meeting make them bored, different ability of speaking make the group discussion that sometimes does not run well. In addition, students are not serious in doing discussion, they discuss the thing outside the topic discussion and sometimes the students do not use the time given properly.

\section{ACKNOWLEDGMENTS}

This article based on research and supported or financial support by IKIP SIliwangi 2019, the writers would like to saya thanks so much for any aid or support in conducting this research.

\section{REFERENCES}

Blatner, A. (2000). Role Playing In Education. Disponibile All'indirizzo: Http://Www. Blatner. Com/Adam/Pdntbk/Rlplayedu. Htm.

Brown, D. (2001). Teaching By Principles. An Interactive Approach To Language Pedagogy (Second Edi). Pearson Education.

Broughton, G., Brumfit, C., Flavell, R., Hill, P., \& Pincas, A. (2003). Teaching English As A Foreign Language (Second Edi). London And New York: Routledge Education.

Creswell, J. . (2014). Research Design: Qualitative, Quantitative And Mixed Methods Approaches (Fourth Edi). Sage Publications.

Harmer, J. (2007). The Practice Of English Language Teaching (Third Edit). Pearson Education.

Hughes, A. (2003). Testing For Language Teachers. Cambrige: Oxford University Press.

Kaswan, \& Suprijadi, D. (2016). Research In English Language Education. Bandung: Putra Praktisi.

Moreillon, J. (2007). Collaborative Strategies For Teaching Reading Comprehension. Chicago: American Library Association.

Roberts, T. S. (2004). Online Collaborative Learning: Theory And Practice. Idea Group Publishing.

Sadikin, I. S., Suprijadi, D., \& Kaswan. (2019). Pedoman Penelitian Eksperimen: Desain, Prosedur Penelitian Dan Analisis Data Dengan Spss. Ikip Siliwangi Bandung.

Singh, K. (2007). Quantitative Social Research Method. Sage Publications.

Tavakoli, H. (2012). A Dictionary Of Research Methodology And Statistics In Applied Linguistcs. Rahnama Press.

Thornbury, S., \& Slade, D. (2007). Conversation: From Description To Pedagogy. Cambridge University Press.

Tint, S. S., \& Nyunt, E. E. (2015). Collaborative Learning With Think-Pair-Share Technique. 
Computer Applications: An International Journal, 2(1), 1-11. Https://Doi.Org/10.5121/Caij.2015.2101

Ur, P. (1996). A Course In Language Teaching: Practice Of Theory. Cambridge University Press.

Uibu, K., \& Liiver, M. (2015). Students ' Grammar Mistakes And Effective Teaching Strategies. International Journal Of Teaching And Education, Iii(1), 70-87. Purnamawati, S., \& Suhartono, L. The Use Of Role Play In Teaching Speaking. Jurnal Pendidikan Dan Pembelajaran, 4(9).

Https://Doi.Org/10.20472/Te.2015.3.1.006

Wang, F., \& Burton, J. K. (2010). Collaborative Learning Problems And Identity Salience : A Mixed Methods Study. 3(1). Https://Doi.Org/10.18785/Jetde.0301.01

Weller, M. (2002). Delivering Learning On The Net: The Why, What And How Of Online Education. London And Newyork: Routledgefalmer.

Yang, Y. (2014). The Implementation Of Speaking Fluency In Communicative Language Teaching: An Observation Of Adopting The 4 / 3 / 2 Activity In High Schools In China. International Journal Of English Language Education, 2(1). Https://Doi.Org/10.5296/Ijele.V2i1.5136 